\title{
Konsentrat Buah Naga Super Red (Hylocereus costaricensis) Sebagai Pewarna Alami dalam Pembuatan Permen Karet Sehat
}

\author{
Agnescia Clarissa Sera ${ }^{1}$, Dwirina Hervilia ${ }^{2}$ \\ ${ }^{1,2}$ Jurusan Gizi, Politeknik Kesehatan Kemenkes Palangka Raya, Indonesia \\ Email: agnesciasera@poltekkes-palangkaraya.ac.id
}

\begin{abstract}
Super Red Dragon Fruit's (Hylocereus costaricensis) Concentrates as Natural Colorants of Healthy Chewing Gum. In Indonesia, chewing gum is still classified as unhealthy snacks due to the content of synthetic dyes. These synthetic dyes can be replaced with natural dyes like anthocyanin and betacyanin, pigments found in super red dragon fruit (Hylocereus costaricensis). This research aimed to investigate color intensity and consumer preferences toward dragon fruit chewing gums and synthetic dyes-containing chewing gums. Five levels $(80 \%, 70 \%$, $60 \%, 50 \%$, and $40 \%$ ) of dragon fruits concentrations used as natural colorants and were compared to carmoisine, rose-pink, and purple synthetic dyes. Pure experimental research with the complete randomized design was employed. Color intensity (RGB value) was analyzed using KruskalWallis statistical test $(\alpha 0.05)$. A total of 80 untrained panelists aged 17-30 years old evaluated the color of chewing gum. Level of panelist preferences was processed descriptively. There were significant color differences in red $(\mathrm{p}=0.037)$ and blue $(\mathrm{p}=0.012)$ in dragon fruit gum groups. There were significant differences between red $(\mathrm{p}=0.023)$, green $(\mathrm{p}=0.018)$ and blue $(\mathrm{p}=0.012)$ in synthetic-colored gum groups compared with $80 \%$ and $60 \%$ concentrate dragon fruit gums. The higher the percentage of the dragon fruit concentrate, the higher the intensity of color produced in chewing gums. Dragon fruit chewing gum with $80 \%$ concentration was preferable among other dragon fruit gum formulations. Carmoisine chewing gum produced sharper color intensity and was preferable among all products.
\end{abstract}

Keywords: Carmoisine, Colour intensity, Healthy chewing gum, Super red dragon fruit

\begin{abstract}
Abstrak: Konsentrat Buah Naga Super Red (Hylocereus costaricensis) Sebagai Pewarna Alami dalam Pembuatan Permen Karet Sehat. Di Indonesia, permen karet masih tergolong sebagai jajanan tidak sehat karena kandungan pewarna sintetisnya. Pewarna sintetis ini sebenarnya dapat diganti dengan pewarna alami, salah satunya dari buah naga super red yang kaya akan pigmen antosianin dan betasianin. Penelitian ini bertujuan untuk mengetahui potensi pigmen alami yang terdapat dalam konsentrat buah naga super red (Hylocereus costaricensis) dalam pembuatan permen karet dengan cara membandingkan intensitas warna dan tingkat kesukaan panelis terhadap permen karet buah naga super red (Hylocereus costaricensis) konsentrat 80\%, 70\%, 60\%, 50\% dan $40 \%$ dengan permen karet yang mengandung pewarna sintetis karmoisin, rose-pink dan ungu. Penelitian bersifat eksperimen dengan rancangan acak lengkap. Intensitas warna (nilai RGB) dianalisa menggunakan uji statistik Kruskal-Wallis $(\alpha 0,05)$. Uji tingkat kesukaan dilakukan oleh panelis tidak terlatih berjumlah 80 orang dari golongan umur 17-30 tahun. Hasil uji hedonik terhadap warna permen karet diolah secara deskriptif. Terdapat perbedaan warna yang signifikan terhadap warna merah $(p=0,037)$ dan biru $(p=0,012)$ pada kelompok permen karet buah naga. Terdapat perbedaan yang signifikan terhadap warna merah $(p=0,023)$, hijau $(p=0,018)$ dan biru $(p=0,012)$ pada kelompok permen karet dengan pewarna sintetis yang dibandingkan dengan permen karet buah naga konsentrat $80 \%$ dan $60 \%$. Semakin tinggi persentase konsentrat buah naga, semakin tinggi pula intensitas warna yang dihasilkan pada permen karet. Permen karet buah naga dengan konsentrasi $80 \%$ merupakan formulasi yang lebih disukai oleh panelis di antara formulasi permen karet buah naga lainnya. Permen karet dengan pewarna sintetis karmoisin memiliki intensitas warna yang lebih tajam dan lebih disukai panelis dibanding permen karet buah naga.
\end{abstract}

Kata kunci: Karmoisin, Intensitas warna, Permen karet sehat, Buah naga merah

Permen karet dapat didefinisikan sebagai permen kenyal yang memiliki daya gelembung setelah dikunyah secara konsisten. Permen ini terbuat dari 4 bahan utama, yaitu gum base, pemanis (sweeteners), pewarna (colors) dan perisa makanan (flavors) (Panda, 2015). 
Berdasarkan sejarahnya, permen karet dibuat dari getah pepohonan. Contohnya, orang Yunani kuno menggunakan damar pohon mastic, orang Amerika Utara memanfaatkan getah pohon cemara dan suku Maya menggunakan getah pohon sapodilla untuk membuat permen karet (Mathews, 2009; Yunita, 2017). Meskipun permen karet telah dijual secara komersil oleh John B. Curtis, seorang pengusaha Amerika pada tahun 1848, baru pada akhir tahun 1869 permen ini resmi dipatenkan oleh William Finley Semple, seorang dokter gigi dari Ohio, Amerika (Yunita, 2017). Sejak saat itu, permen karet dikembangkan dengan menggunakan berbagai pewarna, pemanis dan perisa untuk meningkatkan daya tarik dari produk ini.

Sejak dikembangkannya permen karet, para peneliti menemukan bahwa ternyata produk ini memiliki banyak manfaat. Salah satunya terkait dengan kemampuan kognitif dan suasana hati (mood). Penelitian yang dilakukan di Inggris dan Canada membuktikan bahwa mengunyah permen karet dapat meningkatkan daya ingat dan mengurangi stress (Allen \& Smith, 2011; Lee \& Sergueeva, 2017). Demikian halnya dengan penelitian yang dilakukan di Cina baru-baru ini, permen karet terbukti efektif dan aman digunakan untuk mengobati pasien pankretitis akut stadium awal (Jiang et al., 2017). Lebih lanjut, penelitian yang dilakukan oleh Ruban, Masliy \& Kutsenko (2017) menyimpulkan bahwa permen karet dapat digunakan sebagai salah satu terapi alternatif untuk mengontrol berat badan pasien overweight. Bahkan, permen karet yang yang mengandung nikotin pun kini telah dipatenkan di Amerika Serikat sebagai obat bagi pasien kanker (pharmaceutical chewing gum) (Neergaard, 2017).

Sayangnya, penggunaan permen karet untuk hal-hal yang positif lebih banyak terjadi di negara maju. Di negara berkembang seperti Indonesia, permen karet masih diidentikkan dengan jajanan tidak sehat. Contohnya, dalam penelitian Anugrah, Arifah dan Zulaicha (2012) serta penelitian Febrian, Rasyid dan Noviantika (2013), permen karet termasuk salah satu bentuk jajanan manis yang banyak dikonsumsi oleh anak usia 5-6 tahun dan berpotensi menyebabkan karies gigi. Sebagian besar permen karet komersial yang beredar di pasaran ini mengandung sakarin, aspartame dan acesulfame $\mathrm{K}$ yang tergolong sebagai pemanis buatan (Silalahi, Chahaya \& Marsaulina, 2010). Di samping itu, tartrazin, karmoisin, titanium dioksida, indigotin dan merah allura juga kerap kali digunakan sebagai pewarna tambahan pada permen karet (Ambarsari, Qanytah \&
Sarjana2012; Silalahi, Chahaya \& Marsaulina, 2010). Tingginya kandungan bahan tambahan pangan seperti pemanis dan pewarna buatan yang mungkin terdapat pada permen karet komersil inilah yang menyebabkan produk ini mendapat kesan negatif di kalangan masyarakat Indonesia.

Pemanis dan pewarna sintetis umumnya digunakan oleh produsen karena alasan efisiensi biaya dan efektivitas produksi. Padahal, apabila dikonsumsi dalam jangka panjang, makanan yang mengandung bahan tambahan pangan sintetis tersebut dapat memicu munculnya penyakit seperti gangguan syaraf otak dan kanker (Yusuf, Ramdhan \& Rochmawati, 2016; Pratama, Ciptono \& Sudarsono, 2017). Untuk itu, pemerintah Indonesia melalui Badan Pengawasan Obat dan Makanan (BPOM) menganjurkan pembatasan konsumsi pangan yang mengandung pewarna dan pemanis sintetis dan menggantinya dengan bahan-bahan alami yang didapat dari tumbuhan, tanaman herbal, sayuran ataupun buah-buahan. Salah satu bagian buah yang berpotensi digunakan sebagai bahan tambahan makanan alami adalah buah naga super red.

Studi literatur menunjukkan bahwa selama ini buah naga belum dimanfaatkan secara maksimal. Buah naga umumnya hanya dikonsumsi langsung ataupun diolah menjadi minuman sari buah naga. Untuk itulah penelitian ini dibuat, dimana ekstrak buah naga super red (Hylocereus costaricensis) akan digunakan sebagai pengganti bahan pewarna buatan pada permen karet sehat. Secara khusus, penelitian ini bertujuan untuk membandingkan intensitas warna dan tingkat kesukaan permen karet dengan pewarna sintetis dan permen karet sehat dengan pewarna dari ekstrak buah naga super red.

\section{METODE}

Penelitian ini merupakan eksperimen murni dengan rancangan acak lengkap. Penelitian dibagi menjadi 2 tahap. Pada tahap 1 akan dipilih 2 formulasi permen karet buah naga yang paling disukai panelis dan kemudian akan dibandingkan dengan permen karet dengan pewarna sintetis karmoisin, rose-pink, dan ungu pada tahap 2.

Eksperimen ini dilakukan di Laboratorium Pangan dan Laboratorium Organoleptik Jurusan Gizi Poltekkes Kemenkes Palangka Raya pada bulan Oktober-Desember 2017.

Sebelum melakukan penelitian tahap 1 dan 2, terlebih dulu dilakukan ekstraksi buah naga super dengan mengikuti prosedur berikut ini
a. Buah naga super red (Hylocereus costaricensis) dengan berat rata-rata 350- 
550 gr dibeli langsung dari petani lokal buah naga merah pada musim panen. Buah dibersihkan dan dipotong-potong menggunakan pisau, ditimbang dengan timbangan digital, dihancurkan dengan blender dan direndam dalam pelarut aquades dan asam sitrat $10 \%$ (food grade) selama 1 hari sebelum dilakukan proses ekstrasi.

b. Proses ekstraksi buah naga dilakukan menggunakan metode MAE (Microwave Assissted Extraction) dimana bubur buah naga dipanaskan dalam microwave berdaya 800 watt selama 6 menit. Proses ini terutama bertujuan untuk memaksimalkan pigmen yang akan diekstrak dari kulit buah naga (Ingrath, Nugroho \& Yulianingsih, 2015).

c. Selanjutnya, bubur buah naga disaring 2 kali menggunakan kain saring (kain blacu) dan kertas saring kemudian didistilasi dengan rotary vacuum evaporator untuk mendapatkan ekstrak buah naga.

d. Dari ekstrak buah naga tersebut dibuatlah larutan dengan konsentrasi 80\%, 70\%, 60\%, $50 \%$ dan $40 \%$.

Setelah dilakukan proses ekstraksi dan pembuatan konsentrat, langkah berikutnya adalah pembuatan produk permen karet. Dengan konsep trial and error, peneliti sebelumnya mencoba beberapa resep pembuatan permen karet yang diambil dari internet dan menambahkannya dengan ekstrak buah naga. Setelah melakukan beberapa kali percobaan, didapatkanlah resep standar yang dapat menghasilkan permen karet buah naga dengan tekstur dan warna yang sesuai dengan harapan peneliti. Bahan yang digunakan dalam pembuatan permen karet tersebut dapat dilihat pada Tabel 1. Resep dapat di-scale up untuk membuat permen karet dalam jumlah yang banyak.

Tabel 1. Resep Dasar Permen Karet Buah Naga

\begin{tabular}{lr}
\hline \multicolumn{1}{c}{ Bahan } & \multicolumn{1}{c}{ Jumlah } \\
\hline Gula halus & $27,5 \mathrm{gr}$ \\
Xanthan gum & $9 \mathrm{gr}$ \\
Sirup jagung & $5 \mathrm{ml}$ \\
Gliserin & $2 \mathrm{ml}$ \\
Ekstrak buah naga & $2 \mathrm{ml}$ \\
Asam sitrat & $1 \mathrm{gr}$ \\
\hline
\end{tabular}

Pembuatan permen karet sehat buah naga mengikuti prosedur sebagai berikut:

a. Sirup jagung, gliserin, asam sitrat dan ekstrak buah naga dicampur menjadi satu dalam sebuah wadah hingga menjadi campuran yang homogen. b. Tambahkan xanthan gum dan gula halus ke dalamnya untuk membuat adonan permen karet.

c. Adonan kemudian diuleni hingga kalis, dipipihkan dengan ketebalan $5 \mathrm{~mm}$ dan dipotong dengan ukuran rata-rata $1 \mathrm{~cm} \times 3$ $\mathrm{cm}$.

d. Permen karet kemudian dikemas menggunakan kertas minyak (wax paper).

Permen karet dengan pewarna sintetis juga dibuat mengikuti resep standar di atas. Namun, ekstrak buah naga diganti dengan pewarna karmoisin CI 14720, rose pink (campuran pewarna Tartrazine (E102), Quiloline Yellow (E104), Sunset Yellow FCF (E110), Carmoisine (E122) dan Allura red (E129)) dan pewarna sintetis ungu (campuran pewarna biru berlian CI 42090 dan karmoisin CI 14720).

Sebelum dilakukan pengukuran terhadap intensitas warna dan tingkat kesukaan panelis, seluruh sampel permen karet diberi kode acak. Intensitas warna diukur dengan menggunakan aplikasi smartphone colorimeterversi 3.5.2 yang diproduksi oleh Research Lab Tools, Sao Carlos, SP. Intensitas warna dicatat dalam bentuk nilai RGB (Red, Green, Blue).

Sebanyak 80 orang panelis tidak terlatih dari golongan umur 17-30 tahun diminta tanggapannya terhadap perbandingan warna seluruh sampel yang diuji dan tingkat kesukaannya terhadap warna dari produk permen karet dengan mengisi formulir uji hedonik yang telah disiapkan oleh peneliti.

Data intensitas warna dalam bentuk nilai RGB dianalisa secara statitistik menggunakan statistik uji beda lebih dari 2 kelompok nonparametrik Kruskal-Wallis dengan tingkat kepercayaan 95\%. Data tingkat kesukaan dari uji hedonik diolah dengan melakukan pengelompokkan dan penghitungan persentase terhadap pilihan responden dan disajikan secara deskriptif.

\section{HASIL}

Tabel 2 menunjukkan kombinasi nilai RGB dan warna yang dihasilkan pada permen karet buah naga super red dan permen karet dengan pewarna sintetis. Secara umum, jenis warna yang dihasilkan pada permen karet buah naga adalah merah muda keunguan. Tabel 2 juga menunjukkan bahwa pewarna sintetis, terutama karmoisin dan rose-pink memiliki intensitas warna yang lebih tajam/kuat bila dibandingkan dengan pewarna alami dari buah naga super red. 
Namun, permen karet buah naga konsentrat $40 \%$ karet dengan pewarna sintetis ungu. memiliki warna yang serupa dengan permen

Tabel 2. Kombinasi Nilai RGB dan Warna yang Dihasilkan pada Sampel Permen Karet

\begin{tabular}{|c|c|c|c|c|c|}
\hline Sampel & $\mathbf{R}$ & $\mathbf{G}$ & B & Warna & Jenis warna \\
\hline $\begin{array}{l}\text { Permen karet buah naga } \\
\text { konsentrat } 80 \%\end{array}$ & 199 & 136 & 144 & & Light-red \\
\hline $\begin{array}{l}\text { Permen karet buah naga } \\
\text { konsentrat } 70 \%\end{array}$ & 195 & 134 & 139 & & Light-red \\
\hline $\begin{array}{l}\text { Permen karet buah naga } \\
\text { konsentrat } 60 \%\end{array}$ & 196 & 145 & 142 & & Light-red \\
\hline $\begin{array}{l}\text { Permen karet buah naga } \\
\text { konsentrat } 50 \%\end{array}$ & 195 & 145 & 136 & & Light-red-orange \\
\hline $\begin{array}{l}\text { Permen karet buah naga } \\
\text { konsentrat } 40 \%\end{array}$ & 192 & 140 & 129 & & $\begin{array}{l}\text { Light-red-orange- } \\
\text { brown }\end{array}$ \\
\hline $\begin{array}{l}\text { Permen karet dengan pewarna } \\
\text { sintetis karmoisin }\end{array}$ & 203 & 71 & 92 & & Red \\
\hline $\begin{array}{l}\text { Permen karet dengan pewarna } \\
\text { sintetis rose-pink }\end{array}$ & 208 & 80 & 103 & & Pink-red \\
\hline $\begin{array}{l}\text { Permen karet dengan pewarna } \\
\text { sintetis ungu }\end{array}$ & 175 & 139 & 127 & & $\begin{array}{l}\text { Light-red-orange- } \\
\text { brown }\end{array}$ \\
\hline
\end{tabular}

Uji statistik Kruskal-Wallis dilakukan terhadap kelompok permen karet buah naga konsentrat $80 \%, 70 \%, 60 \%, 50 \%$ dan $40 \%$ untuk melihat perbedaan warna pada produk permen karet buah naga. Hasil uji statistik membuktikan terdapat perbedaan warna yang signifikan terhadap warna merah (red) dan biru (blue) dengan nilai signifikansi masing-masing 0,037 dan 0,012 (Tabel 3).

Tabel 3. Hasil Uji Perbedaan Nilai RGB pada Lima Konsentrat Buah Naga

\begin{tabular}{lrcccc}
\hline $\begin{array}{l}\text { Nilai } \\
\text { RGB }\end{array}$ & Mean \pm SD & Min & Max & n & $\begin{array}{c}\boldsymbol{p} \\
\text { value }\end{array}$ \\
\hline Nilai & $195,93 \pm$ & 192 & 202 & 15 & $0,037^{*}$ \\
Red & 3,348 & & & & \\
Nilai & $140,00 \pm$ & 132 & 148 & 15 & 0,132 \\
Green & 4,870 & & & & \\
Nilai & $138,40 \pm$ & 129 & 146 & 15 & $0,012^{*}$ \\
Blue & 5,316 & & & & \\
\hline
\end{tabular}

*) ada perbedaan

Demikian pula halnya pada kelompok permen karet dengan pewarna sintetis karmoisin, rose-pink dan ungu yang dibandingkan dengan permen karet buah naga konsentrat $80 \%$ dan $60 \%$ (Tabel 4). Uji Kruskal-Wallis menunjukkan adanya perbedaan yang signifikan terhadap warna merah $(p=0,023)$, hijau $(p=0,018)$ dan biru $(0,012)$ dari kelima kelompok permen karet tersebut.
Tabel 4. Hasil Uji Perbedaan Nilai RGB pada Pewarna Sintetis dan Dua Konsentrat Buah Naga

\begin{tabular}{lrcccc}
\hline $\begin{array}{l}\text { Nilai } \\
\text { RGB }\end{array}$ & Mean \pm SD & Min & Max & n & $\begin{array}{c}\boldsymbol{p} \\
\text { value }\end{array}$ \\
\hline Nilai & $195,80 \pm$ & 172 & 208 & 15 & $0,023^{*}$ \\
Red & 11,92 & & & & \\
Nilai & $114,20 \pm$ & 65 & 148 & 15 & $0,018^{*}$ \\
$\begin{array}{l}\text { Green } \\
\text { Nilai }\end{array}$ & 112,01 & & & & \\
$\begin{array}{l}\text { Blue } \\
\text { Blu }\end{array}$ & 22,78 & 86 & 146 & 15 & $0,012^{*}$ \\
ada perbedaan & & & & & \\
\hline
\end{tabular}

Hal ini dikonfirmasi oleh 80 panelis yang menilai produk permen karet, dimana seluruh panelis menyatakan terdapat perbedaan warna, baik di antara kelima jenis permen karet buah naga, maupun saat permen karet buah naga konsentrat $80 \%$ dan $60 \%$ dibandingkan permen karet dengan pewarna sintetis.

Pada eksperimen tahap 1, dilakukan uji hedonik untuk menilai tingkat kesukaan panelis terhadap warna permen karet buah naga. Dari kelima produk tersebut, warna produk yang paling disukai panelis adalah permen karet buah naga konsentrat $60 \%$, diikuti oleh permen karet buah naga konsentrat $80 \%$, permen karet buah naga konsentrat $70 \%$, permen karet buah naga konsentrat $50 \%$ dan permen karet buah naga konsentrat 40\% (Gambar 1).

Dengan demikian, produk permen karet buah naga konsentrat $60 \%$ dan $80 \%$ ini selanjutnya dipilih untuk dibandingkan dengan permen karet yang berwarna sintetis pada eksperimen tahap 2. 


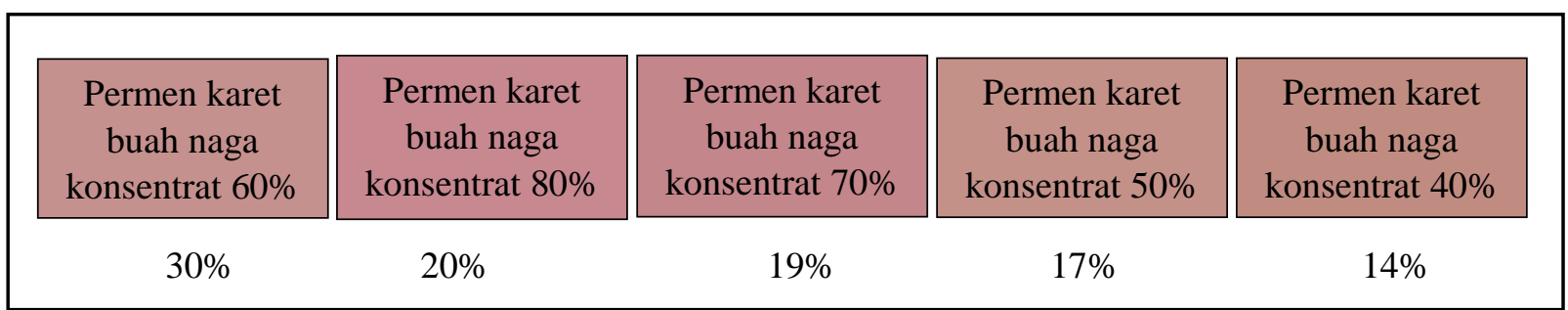

Gambar 1. Tingkat Kesukaan Panelis terhadap Warna Sampel Permen Karet Buah Naga

Tingkat kesukaan panelis terhadap warna permen karet pada eksperimen tahap 2 digambarkan secara rinci pada gambar 2. Dari total 80 orang panelis, $40 \%$ di antaranya menyukai permen karet yang dibuat dengan penambahan pewarna karmoisin, 35\% panelis menyukai permen karet dengan pewarna sintetis rose-pink dan $1 \%$ panelis menyukai permen karet dengan pewarna sintetis ungu. Hanya 19\% panelis menyukai permen karet sehat dengan pewarna alami buah naga konsentrat $80 \%$ dan $5 \%$ lainnya menyukai permen karet buah naga konsentrat $60 \%$.

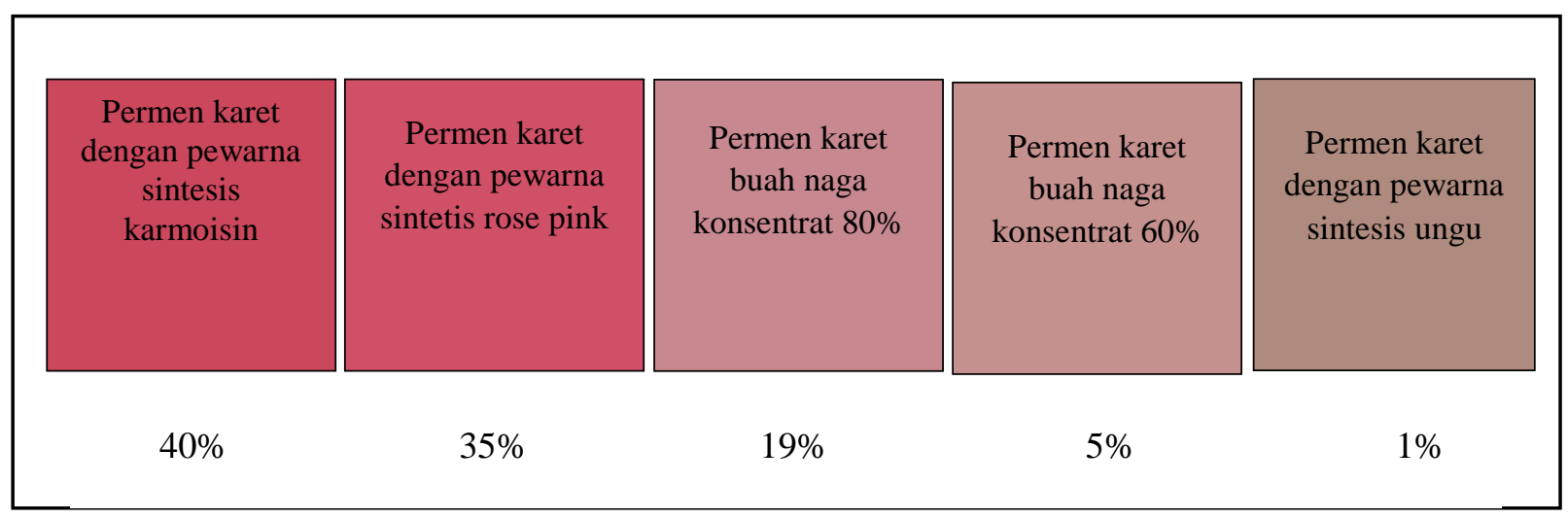

Gambar 2. Tingkat Kesukaan Panelis terhadap Warna Sampel Permen Karet dengan Pewarna Sintetis dan Permen Karet dengan Pewarna Alami Buah Naga

\section{PEMBAHASAN}

Warna merah muda keunguan pada permen karet buah naga berasal dari pigmen antosianin dan betasianin yang terkandung di dalam buah naga (Ingrath, Nugroho \& Yulianingsih, 2015). Buah naga super red yang digunakan merupakan buah naga masak yang memiliki kandungan antosianin dan betasianin tertinggi (Harjanti, 2016). Dari tabel 2, dapat dilihat bahwa semakin rendah persentase konsentrat buah naga yang digunakan, semakin pucat warna yang dihasilkan.

Permen karet pembanding dibuat dengan menambahkan pewarna sintesis karmoisin, rose- pink dan ungu. Pewarna sintetis karmoisin/carmoisine (CI No. 14720 atau E122) merupakan salah satu pewarna yang sering digunakan pada makanan, seperti permen, selai, produk bakery, pudding, jelly, yoghurt, keju dan sirup. Pewarna sintesis karmoisin memberikan warna merah hingga marun. Dengan menggunakan standar resep permen karet buah naga, permen karet dengan pewarna sintesis karmoisin menghasilkan warna merah terang. Berdasarkan Peraturan Menteri Kesehatan Nomor 33 Tahun 2012, pewarna ini diizinkan untuk digunakan dengan batas maksimal $4 \mathrm{mg} / \mathrm{kg}$ berat badan. 
Pewarna sintesis rose-pink merupakan pewarna makanan komersil dari campuran antara pewarna Tartrazine (E102), Quiloline Yellow (E104), Sunset Yellow FCF (E110), Carmoisine (E122) dan Allura red (E129). Pewarna ini biasanya digunakan pada makanan ringan, cake, icing, permen dan es krim. Saat diaplikasikan pada permen karet, pewarna rose-pink ini menghasilkan warna merah muda yang cukup intens dibandingkan dengan warna permen karet buah naga.

Pewarna sintesis ungu merupakan bahan tambahan pangan campuran dari pewarna biru berlian (CI 42090) dan karmoisin (CI 14720). Pewarna ini menghasilkan warna ungu dengan batas penggunaan pada makanan sebesar 100 $\mathrm{mg} / \mathrm{kg}$ bahan. Dengan menggunakan standar resep permen karet buah naga, permen karet dengan pewarna sintesis ungu menghasilkan warna ungu pucat hampir menyerupai warna permen karet buah naga konsentrasi $40 \%$.

Intensitas warna yang terdapat pada permen karet dengan pewarna sintetis karmoisin dan rose-pink memiliki nilai warna merah (red) karet lainnya. Selain itu, kombinasi nilai RGB pada kedua jenis permen karet ini didominasi oleh nilai warna merah (red). Dengan demikian, intensitas warna permen karet karmoisin dan permen karet rose pink menghasilkan warna merah muda yang lebih tajam dibandingkan produk permen karet lainnya. Tampaknya, pigmen alami yang terdapat pada buah naga super red yang diekstrak pada penelitian ini belum mampu memberikan warna setajam pewarna sintetis karmoisin dan rose pink.

Dalam konsentrasi rendah, pewarna sintesis dapat memberikan warna yang lebih tajam dibandingkan pewarna alami (Harjanti, 2016; Simon et al., 2017). Untuk menghasilkan warna yang lebih tajam, pewarna alami harus ditambahkan dalam jumlah yang banyak atau dalam konsentrasi yang lebih tinggi. Hal inilah yang menjadi salah satu penyebab penggunaan pewarna alami kurang disukai oleh produsen makanan. Karena dari segi ekonomi, hal ini tentu memakan biaya yang lebih besar dibandingkan bila menggunakan pewarna sintesis.

Di sisi lain, pewarna sintesis umumnya bersifat lebih stabil bila dibandingkan dengan pewarna alami (Lazuardi, 2010). Pada penyimpanan dengan suhu dan $\mathrm{pH}$ yang tidak terkontrol serta adanya paparan sinar matahari akan mengakibatkan degradasi pigmen pada pewarna alami (Hutchings, 1999). Sebaliknya, pewarna sintetis cenderung lebih tahan terhadap perubahan suhu, $\mathrm{pH}$, cahaya serta kelembaban lingkungan tempat penyimpanan. Ketidakstabilan pewarna alami ini sesungguhnya dapat dikoreksi dengan penerapan teknologi mikroenkapsulasi dan nanoenkapsulasi (Sohail, et al. 2012). Pada prinsipnya, dalam teknologi enkapsulasi ini, pigmen akan dilindungi dari kondisi lingkungan yang tidak mendukung. Bahan pembungkus memiliki permeabilitas selektif dan biasanya berupa gelatin (Lam \& Chui, 2013; Mahdavi et al., 2014). Hanya saja, teknologi ini masih tergolong mahal.

Walaupun pewarna alami memiliki kekurangan di atas, pewarna alami merupakan zat aktif yang masih dianggap aman (Simon et al., 2017). Sejauh ini, belum ada penelitian yang menemukan efek samping pigmen tanaman sebagai pewarna alami makanan terhadap kesehatan manusia. Sebaliknya, penggunaan pewarna sintetis pada makanan perlu mendapat perhatian. Hal ini disebabkan karena pewarna sintetis dibuat dari zat kimia yang dapat memberikan efek samping pada organ tubuh manusia bila terakumulasi dalam jumlah tertentu. Di samping itu, dalam proses pembuatan pewarna sintetis, seringkali ditemukan adanya residu arsen, timbal dan logam berat lainnya hasil dari penambahan asam nitrat dan asam sulfat (Khatoon \& Rai, 2016). Logam berat ini bersifat toksik bagi darah dan sangat membahayakan kesehatan.

Uji statistik Kruskal-Wallis yang ditampilkan pada tabel 3 dan 4 menunjukkan adanya perbedaan warna pada kelima produk permen karet buah naga maupun saat permen karet buah naga konsentrat $80 \%$ dan $60 \%$ dibandingkan permen karet dengan pewarna sintetis membuktikan bahwa mata manusia merupakan indera yang peka terhadap perbedaan warna. Hal ini disebabkan karena adanya sel-sel berbentuk kerucut pada retina mata, yang terdiri dari cone dan rod cells yang sensitif terhadap perubahan warna (Hutchings, 1999). Selain itu, retina mata manusia juga memiliki fotoreseptor untuk tiga warna primer, yaitu merah (red), hijau (green) dan biru (blue) sehingga warna yang dilihat oleh mata manusia merupakan kombinasi dari ketiga warna tersebut (Foroni, Pergola \& Rumiati, 2016). Namun, tampaknya pigmen alami buah naga yang ditambahkan pada permen karet belum mampu meningkatkan daya tarik panelis bila dibandingkan dengan produk permen karet dengan penambahan pewarna sintetis. Bila dikaitkan dengan intensitas warna permen karet dengan pewarna sintetis karmoisin dan rose-pink yang cenderung lebih tajam dibandingkan dengan permen karet lainnya, dapat disimpulkan bahwa panelis cenderung menyukai warna yang lebih tajam/cerah dibandingkan warna yang pucat. 
Di sisi lain, hasil temuan pada gambar 2 juga berbanding terbalik dengan hasil temuan sebelumnya. Pada eksperimen tahap 1 , permenkaret buah naga konsentrat $60 \%$ cenderung lebih disukai dibandingkan permen karet buah naga konsentrat $80 \%$. Namun pada eksperimen selanjutnya, setelah kedua jenis permen karet buah naga ini dibandingkan dengan permen karet beperwarna sintetis, panelis lebih menyukai permen karet buah naga konsentrat 80\% dibandingkan permen karet buah naga konsentrat $60 \%$. Dengan demikian, dapat disimpulkan bahwa formulasi yang dihasilkan dari buah naga konsentrat $80 \%$ lebih baik dalam meningkatkan daya tarik panelis terhadap warna produk permen karet.

Spence (2015) berpendapat bahwa perubahan terhadap intensitas warna pada makanan akan berpengaruh secara dramatis pada preferensi makan seseorang. Pada eksperimen tahap 1, perbedaan warna antar permen karet buah naga tidak terlalu mencolok sehingga panelis cenderung memilih warna yang berada pada posisi di tengah, tidak terlalu terang dan tidak terlalu pucat, yaitu warna permen karet buah naga konsentrat $60 \%$.

Berbeda halnya setelah dibandingkan dengan permen karet yang bewarna sintetis pada eksperimen tahap 2 yang memiliki perbedaan intensitas warna yang cukup mencolok. Hal ini secara tidak disadari oleh panelis, mengubah preferensinya kepada warna yang lebih terang/menarik mata. Oleh karena itu, pada eksperimen tahap 2, permen karet buah naga konsentrat $80 \%$ cenderung lebih disukai dibanding permen karet buah naga konsentrat $60 \%$.

\section{DAFTAR PUSTAKA}

Allen, A.P.\& Smith, A.P. 2011. A Review of The Evidence That Chewing Gum Affects Stress, Alertness and Cognition. Journal of Behavioural and Neuroscience Research, 9(1): 7-23.

Ambarsari, I, Qanytah \& Sarjana. 2012. Penerapan Standar Penggunaan Pemanis Buatan pada Produk Pangan. Perpustakaan Digital Politeknik Negeri Bandung.

\section{SIMPULAN}

Buah naga super red (Hylocereus costaricensis) memiliki pigmen alami yang dapat diekstrak dan digunakan sebagai bahan pewarna alami pada permen karet. Semakin tinggi persentase konsentrat buah naga, semakin tinggi pula intensitas warna yang dihasilkan pada permen karet. Permen karet dengan pewarna sintetis karmoisin dan rose-pink memiliki intensitas warna yang lebih tajam dibandingkan dengan permen karet buah naga.Permen karet buah naga dengan konsentrasi $80 \%$ merupakan formulasi yang lebih disukai oleh panelis di antara formulasi permen karet buah naga lainnya. Namun, bila dibandingkan dengan permen karet dengan pewarna sintetis, permen karet dengan pewarna karmoisin lebih disukai oleh panelis.

Dengan demikian dapat disimpulkan bahwa meskipun buah naga super red memiliki pigmen alami yang berpotensi untuk menjadi bahan substitusi pewarna pada produk permen karet, intensitas warnanya masih lebih lemah dibandingkan pewarna sintetis untuk menimbulkan daya tarik konsumen.

\section{SARAN}

Perlu dilakukan penelitian lebih lanjut untuk meningkatkan intensitas warna dari pigmen alami buah naga super red sehingga mampu menyerupai pewarna sintesis yang memiliki intensitas warna yang kuat dalam konsentrasi rendah. Dalam hal ini, penerapan teknologi enkapsulasi mungkin menjadi salah satu alternatif yang dapat diterapkan untuk meningkatkan kestabilan warna pigmen alami buah naga super red. Di sisi lain, untuk menjamin keamanan produk permen karet, perlu dilakukan penelitian terhadap kadar pewarna sintesis yang terkandung dalam permen karet dengan standar resep yang ada pada penelitian ini.

http://digilib.polban.ac.id/gdl.php?mod=br owse\&op=read\&id=jbptppolban-gdlindrieamba-3115 (Diakses pada 15 Februari 2017).

Anugrah, A.S., Arifah, S.\& Zulaicha, E. 2012. Hubungan Frekuensi Konsumsi Makanan Jajanan Anak terhadap Kejadian Karies Gigi di TK Aisyah Kateguhan Sawit Boyolali. [Doctoral Disertation]. Universitas Muhammadiyah. Surakarta. 
Febrian, Rasyid, R. \& Noviantika, D. 2013. Analisis Hubungan Jenis dan Frekuensi Mengkonsumsi Jajanan Kariogenik dengan Kejadian Rampan Karies pada Anak Usia 5-6 Tahun di Kota Padang. Andalas Dental Jurnal1(1).

http://adj.fkg.unand.ac.id/index.php/adj/art icle/view/1. (Diakses tanggal 15 Februari 2017)

Foroni, F., Pergola, G.\& Rumiati, R.I. 2016. Food Colour Is in The Eye of The Beholder: The Role of Human Trichromatic Vision in Food Evaluation. Scientific reports, 6, 37034.

Harjanti, R.S. 2016. Optimasi Pengambilan Antosianin dari Kulit Buah Naga Merah (Hylocereus polyrhizus) Sebagai Pewarna Alami pada Makanan. Chemica 3(2): 3945.

Hutchings, J.B. 1999. Food Colour and Appearance. Springer-Science + Business Media Dordrecht. UK.

Ingrath, W., Nugroho, W.A.\& Yulianingsih, R. 2015. Ekstraksi Pigmen Antosianin dari Kulit Buah Naga Merah (Hylocereus costaricensis) Sebagai Pewarna Alami Makanan dengan Menggunakan Microwave (Kajian Waktu Pemanasan dengan Microwavedan Penambahan Rasio Pelarut Aquades dan Asam Sitrat. Jurnal Bioproses Komoditas Tropis, 3 (3): 1-8.

Jiang, Z., Liang, H., Huang, Z., Tang, J.\& Tang, L. 2017. Sham Feeding with Chewing Gum in Early Stage of Acute Pancreatitis: A Randomized Clinical Trial. Medical Science Monitor, 23: 623-30.

Khatoon, H.\& Rai, J.P.N. 2016. Agricultural Waste Materials as Biosorbents for The Removal of Heavy Metals and Synthetic Dyes-A Review. Octa Journal of Environmental Research, 4 (3).

Lam, P.K.\& Chui, C.H. 2013. A Novel Green Gelatin-Agar Microencapsulation System with $P$. Urinariaas an Improved Anti-A. Niger Model. Carbohydrate Polymers, 92(1): 877-880.

Lazuardi, R.N.M. 2010. Mempelajari Ekstraksi Pigmen Antosianin dari Kulit Manggis (Garcinia mangostana L.) dengan Berbagai Jenis Pelarut. [Tugas Akhir]. Jurusan Teknik Pangan Fakultas Teknik. Universitas Pasundan. Bandung.

Lee, S.H.\& Sergueeva, K. 2017. Chewing Increases Consumer's ThoughtEngagement During Retail Shopping.
Journal of Retailing and Consumer Services, 35: 127-32.

Mathews, J.P. 2009.Chicle: The Chewing Gum of The Americas, From Ancient Maya to William Wrigley. Tucson: The University of Arizona Press.

Mahdavi, S.A., Jafari, S.M., Ghorbani, M.\&Assadpoor, E. 2014. Spray-Drying Microencapsulation of Anthocyanins by Natural Biopolymers: A Review. Drying Technology an International Journal, 32(5): 509-518.

Neergaard, J. 2017. Medical Chewing Gum. US Patent 002081A1.

Panda, Himadri. 2015. Technology of Confectionery, Chocolates, Toffee, Candy, Chewing \& Bubble Gum, Lollipop and Jelly Products with Formulations. New Delhi: Engineers India Research Ins.

Pratama, A.F., Ciptono \& Sudarsono. 2017. Pengaruh Pemberian Sakarin terhadap Morfometri Fetus Putih (Rattus Norvegicus, L.). Jurnal Mahasiswa Universitas Negeri Yogyakarta 6(1). http://journal.student.uny.ac.id/ojs/index.p hp/biologi/article/view/6054 (Diakses tanggal 15 Februari 2017).

Silalahi, R., Chahaya, I. \& Marsaulina, I. 2010. Analisa Jenis dan Kadar Pemanis Buatan pada Permen Karet yang Beredar di Kota Medan Tahun 2010. [Skripsi]. Universitas Sumatera Utara.

Simon, J.E., Decker, E.A., Ferruzzi, M.G., Giusti, M.M., Mejia, C.D., Goldschmidt, M. \& Talcott, S.T. 2017. Establishing Standards on Colors from Natural Sources. Journal of Food Science, 82(11): 2539-2553.

Sohail, A., Turner, M.S., Coombes, A.\& Bhandari, B. 2012. Food and Bioprocess Technology, 6(10): 2763-2769.

Spence, Charles. 2015. On The Physicological Impact of Food Colour. BioMed Central, 4(21): 1-16.

Yunita, C.M. 2017. Permen Karet. https://www.academia.edu/8193440/PER

MEN_KARET (Diakses tanggal 15

Februari 2017).

Yusuf, Y., Ramdhan, M.\& Rochmawati, Y. 2016. Analysis on Level of Saccharin And Cyclamate Additives Inside CupPackaging-Drink at SD Karang Tengah, Tangerang City. ADRI International Journal of Medical and Health Sciences, $1(1)$. 